\title{
THE ART OF GODDESS MANASA IN EASTERN INDIA; AN OVERVIEW
}

\author{
NILKANTA DAS \\ Research Scholar, Department of Art History, Visva-Bharati University, Santiniketan. India
}

\begin{abstract}
Current expressions of the goddess Manasa in context of the art history of Eastern India, studies and tracing of art, literature, music, religious practices and different other social issues of those lands and people are in the consideration for this paper.

The site of our story lies in the Eastern Indian region, i.e. the undivided Bengal (west and east Bengal), Bihar and Orissa. People of these lands have been familiar with the name of 'Manasa' for over five hundred years or so. Adding with that the image that comes with this name has been known for almost a thousand years. The oldest mention is that of Sungai Bhattarikh or Sungai Devi is an eleven century Nepali stone inscription. We find relevance of the snake goddess in the art of the Buddhist and Jains spanning centuries between the 6th and 12th. In the lands of the eastern India where Bengalis have been domain art for the centuries worship of Manasa is quite popular till the present times. The artistic expressions of the goddess through diversetraditional folk arts of Bengal arethe central motives.

The Manasa a songs or culture has been quite popular in the downstream regions of Eastern Bengal from historical times. In colonial time with the partition of Indo-Bangla people by large group has been migrated from Bangladesh to the Indian region of West Bengal and in north-eastern state of Tripura and Assam. Impressions of the Manasa culture are still traceable in them.
\end{abstract}

KEYWORDS: “Snake-goddess”, “Sungai Devi”, “Manasa”, “Bengali tradition”, “folk art”

Received: Oct 14, 2020; Accepted: Nov 4, 2020; Published: Dec 05, 2020; Paper Id.: IJHRDEC20205

\section{INTRODUCTION}

The snake goddess existed in different cultures of the world from ancient times. The consciousness and knowledge about snakes forms of herpetology co-existed with that. Similarly in India there is a vast store of knowledge, folklores and stories on snakes. Among these the goddess Manasa stands out as a unique example of a sign of ancient wisdom. The etymology of "Manasa" indicates a non-Aryansource which is obscure to the scholars. Noneof the Sanskrit textsby Paninimentionthe word Manasa as a snake goddess. Kshitimohan Sen and Nalinikanta Bhattashali respectively mentionthe South Indian snake goddess 'Mane Manchanmma' or 'Manchanmma' as the origin of goddess Manasa. According to K. Sen followed by N. Bhattashali during the tenth to twelve century with the intervention of Sena dynasty in Bengal, the southern Manchanmma transformed into Manasa.

The myth of the goddess in Bengal has been expended and explored in details and by large in the 'Manasa-mangal kavya'. The sacred books of Manasa-mangal relates the great name of the goddess, which has been written or composed during fifteenth to nineteenth century in Bengal. The term Mangalkavya can be translated as "eulogistic poetry". Names of almost a hundred and sixty poets can be known from the manuscript of Manasa-mangal kavya found in eastern India. The poet worked over an area of these lands. It should be noted that like in literature, Manasa-mangal text has become an important constitute of Bengali music as well. On the other hand Manasa- 
mangal clearly describes the iconography of the goddess and also the concept of her worship.

The inhabitants of the Bengal territory have been familiar with the name of Manasa since five hundred years or more than that. And the familiarity with the image of the goddess veiled under this name can be traced back to one thousand or twelve hundred years.

It is through the composition and promotion of Mangal Kavya, especially Manasa-mangal Kavya at the beginning of the history of Bengali literature, the goddess Manasa becomes familiar to all of us. Though the snake goddess enjoys a history of thousand years or more than that, the existence of its erstwhile name could not be traced until the arrival of Manasa-mangal Kavya three or four hundred years ago. But scholars are still in darkness regarding the name the snake goddess used to be called after in the ancient period, much before the name Manasa came into existence. However, the oldest name of the goddess that is Svabgai or Svamgai bhattarakih is found in a Nepali stone inscription belonging to 11th century. Various instances of Manasa in art are found in Buddhism and Jainism between the 6th and 12th centuries. Those art works cannot be regarded as Manasa, but one can notice striking similarities between these art works and the artistic features of Manasa. Therefore it is easy to assume that the artistic/visual features of the goddess, which became popular in the later period of medieval age, had its artistic source in the metal and stone sculptures of the goddess belonging to its previous period.

The history of the snake goddess or the medieval Manasa is an almost unexplored and un-investigated field of study. Many scholars have discussed and given their opinion on the iconography of goddess Manasa, in different way. But some of them are rather debatable for her identification as Manasa. The first attempt to treat the subject systematically is that of Nalinikanta Bhattasali in his Iconography of Buddhist and Brahmanical Sculptures in the Dacca Museum, but the author did not raise any question on her identification as Manasa. D.C. Sen`s History of Bengali Language and Literature and some works in Bengali devotes a few pages to her, but there the subject is treated in connection with the study of medieval Bengali literature. Thus, many scholars namely, Kshitimohan Sen, Jitendra Nath Banerjee, P. S. Rawson, T. W. Clark, Brighenti, and Enamul Haque have done their research without questioning her identification as Manasa. The next important move has been taken by A. Bhattacharya, in his Bangla Mangal Kavyer Itihas and the Sun and Serpent lore which furnishes some more information relating to the goddess, against the general background of serpent worship in India. Though, his book primarily deals with the history of medieval literature. Dr. Pradyot Kumar Maity and Gouriswar Bhattachriya both have raised the question of her identification as Manasa, but their works are mostly dependent on the literary sources. Then in his book Manasa Charit, Swami Sankarananda, has attempted to throw fresh light on the subject. $\mathrm{He}$ is one of the scholars who tried to prove that Manasa is a Vaidik (Aryan) goddesses. But this work is also based on only an analysis of the medieval Manasa Mangalkavya. A recent work, mainly a collection of essays on serpent-cult and Manasa edited by Anjan Sen and Sk. Makbul Islam has clearly states the problem regarding the name and iconography of Manasa with a wider perspective on the goddess in diverse aspects. In an essay of the book Professor Gautam Sengupta draws the conclusion that the namesSunga, Suvamgai, Janguli etc. are an ancient tradition and it indicates a continuous tradition of medieval snake goddess Manasa of Bengal.

There are above hundred images of anthropomorphic snake goddess dated from tenth to twelve century excavated from different parts of East and West Bengal, Assam, are preserved in many museum of this region including some in abroad. The stone and bronze images of the snake goddess of Pala and Sena dynasty in Bengal are the earliest source of medieval Manasa images. Pictorially the goddess is always seated under the expanded hood of the snake. In almost all the 
ancient images, a child Asthika who is supposed to be the son of Manasa was sculpted. In the images of later ages instead of a child the Devi carries a snake. She sits on the lotus in either a Lalitasana mudra or in Padmasana, Sukhasana, Baddhapadmasana, Vajraparyankasana mudra (diversesitting posture). (Fig. 1)

Both two-handed and four-handed images of the goddess have been found. In the two-handed idol, it is found either she carries a snake or son (Asthika) in her left hand and the other has been portrayed in 'varada mudra' (fearlessness gesture of hand). However in four handed Manasa images, a pot is held in her upper left hand, a snake in her upper right hand, a rosary in her lower right hand, and a scripture in her lower left hand. In these images, we notice many ornamentssuch as kankanas, bahubalas, hara, upavita, katibandha, katisutra and patrakundalas. There is sometimes variation in the visual construction of an image, but the motifs of pot, scripture, rosary, snake, Asthika remain unchanged. Other than these, a small ghat (pitcher), Sijua (belonging to the Euphorbia genus) plants, and a plate full of offerings are kept beside the feet of the goddess. There are also two miniature bearded men positioned on either side of the deity. They are identified as Dhamai, Jaratkari, Asthika, or Manchashree. The goddess is full of beauty, youth and vigour; her bosom and waist remain uncovered. (Fig. 2)

Beside the tradition of stone and bronze images of the goddess there was parallel tradition of image making in diverse folk mediums. We have record of such Manasa Pata painting (traditional scroll painting), Manasa Ghot (traditional pitcher) and many other anthropomorphic and zoomorphic forms of the goddess in folk tradition existing from medieval period. A huge collection of these folk artefacts of goddess Manasa can be seen in Gurusaday Museum in Kolkata. In addition the tradition of clay idol making and other symbolic forms of Manasa images in present Bengal is a continuity of an ancient art historical tradition. Despite the fact, in the present iconography of the goddess there is a striking evolution. The earlier snake goddess appears with snake canopy, sitting on lotus, son Astika on her lap, sage Jaratkaru in the bottom of the image. The present snake goddess Manasa appear with her bahana (bearer of the goddess) swan, and her ayudha (weapons of the goddess) snake, her asana (sit of the goddess) lotus (Fig. 3); sometimes appear with the other characters of Manasa-mangal kavya (Fig. 4). In some case the goddess comes with a boat sitting along with the family of Chand Sadagar (the merchant according to Manasa-mangal story) (Fig. 5), sometime with snake maiden or with a snake chariot (Fig. 6 \& 7). Principally the present iconography stands with the story of goddess Manasa according to Manasa-mangal kavya.

The tradition and the character changing over time can be traced from the elements present in the literature and art representing the goddess Manasa. Predominantly she is the goddess of snakes. She saves one from dangers, fulfils wishes. She is the core of light, endless in her glory. The impersonation of the goddess remains intangible and elevate in moment of birth, death, marriage etc. she is the symbol of the power of woman. She is in her youth, like the way a snake stays young by shedding its skin. She is behind the cycles of creation, fertility, sustenance and destruction. Thus the goddess can be seen as one of the mother goddess or a form of the 'Shakti' cult. Though the region of Bengal or the 'Eastern' part of India have been considered as an important space of Shakti (power) worship. Histories of the various goddesses have been written here. Most of them are being still worshiped. Manasa is one of them.

Since Manasa is born out of mind there is no need of any construction or physical base and elaborate proceedings of worship for her. The worship is outside the realm of Brahminical control and knowledge. No temple or special architecture is needed. This is a fact that a number of Manasa idol have been found from throughout territory, but no significant temple has been found. In contemporary time there are temples erected for her. Specifically in Tripura and Silchar, South Assam, one can see Manasa puja as an important institution, spread out more or less in all the subdivision of 
those mentions state.

In this area it is also been keenly noticed that those who are not having temple in their houses they never worship to Manasa everyday but they take the active part of worshipping Manasa including the bisorzon (immersion of the idol in the next day of worship) once in every year religiously. Instead of immersion some of the community people keeps the idol alone under the big banyan trees, the name of the place is called thaan in Bengali. Thaan is a place of isolation which is untouchable area for spiritual resting place of idols. The holy book of Manasa Mangal Kavya passes to all the neighbouring houses of those who are not having that very book,for reciting. In this way that holy book reads aloud to every house by rotation during the month of June- July-August. Those who are not having idols they worship to the printed pot, or karandi (made of banana plant, decorated with coloured paper and installed a printed pot inside). Though the anthropomorphic image takes the main rule in Tripura and Assam both.

Cultural literature of the goddess Manasa flourished and is still empowered by drawing from diverse folk tradition. The Manasa a songs or culture has been quite popular in the downstream regions of Eastern Bengal from historical times. In colonial time with the partition of Indo-Bangla people by large group has been migrated from Bangladesh to the Indian region of West Bengal and in North-eastern state of Tripura and Assam. Impressions of the Manasa culture are still traceable in them. Not going into the complications of the partition and its politics, we are content to engross and discuss the flow of art, culture that often overlooks time and space both. In this content it can be mentioned that in Tripura and Southern Assam of Barak Valley cultural influence of the East Bengals population is in the rise. In these parts, the Manasa puja is organised in a huge and splendours more than that of even Durga Puja (worship).

In the living folk of Manasa the art and craft of clay is taken care of by two sorts of professionals. The Potter or Kumarand the Murtikar or the idol maker. The potter uses the wheel to create Ghaut (pot), Hnari (pipkin), Shara (plate) and other terracotta objects. The potter improvises the form of the pot or the pitcher to an idol of Manasa. Sometime they need some modulation and modelling as well. Yet this creation is mainly based on the wheel. The zoomorphic forms of Manasa idol made by them has different names such as Chatol ghaut or Ghaut Bishahari, Bish ghaut or Bish Naga, Ashta Naga, Naba Naga or Naya Naga, Biallish Naga, Neta or Padma ghaut etc. (Fig. 8).

On the other hand in the work of urban idol makers they create anthropomorphic forms of the earthen mother goddess. The three dimensionality of the image is rather emphasised. These forms are named as Naga Ratha, Rong Bishahari, Pat Bishahari, Jaya Bijaya Bishahari, Darai Bishahari, Nonka Bishahari etc. (Fig. 9).

In the capital city of Agartala also, during the month of July-August (Bengali Sravan month) the lore of the goddess Manasa pulses in the air. Songs from Manasa-mangal hover in the space and the potters' hands and wheels go busy churning out Mangal-ghatas (traditional good-wish pots). In the Sravan issues of regular journals and magazines pieces on Bishahari, Padmabati and Padma on the crystal drops ("sphotik jawle padma") are published. This reflects that the subject of the goddess Manasa is a popular issue in the cultural milieu of the East-Bengal. I found that at-least one hundred or more Manasa idols are made in every standard potter's workshop in Silchar and Agartala. Especially the Howrah Market workshop near bat-tala bara-bridge, the Gandhighat workshop, the Aralia, Jogendranagar, Jagharimura (Ramthakur Sangha), North Jogendranagar, Bonkumari, Rabindranagar Rentus, Borduali in Agartala and Bilpar in Silchar, all are active places of the art and craft of idol- making.

Herein the form of woman is kumari ( the form of mother goddess as an adolescent girl), and somewhere jubotee 
(the form of mother goddess as young woman) could be seen alone in sitting position with her group of snake. Out of four hands on the right downwards hand is in the gesture of avaymudra, and in the left downward hand holds a big snake, and in the backside both of the hand holds two small snakesrespectively. On the right side of her leg is swan, and in some idols the neck of the swan is in dwelling position on the right. In some cases two swans are also found by the two sides of the goddess. In front of the goddess there is a mongol ghot (auspicious pitcher), with a green coconut and amropolli (mango leaf) on the top, bellow the pot there are harvested rice grain. There is a new shari or cotton towel is given on top of the ghot, where two snakes are near to that pitcher and two more are in bit distance to that. The goddess is mainly seen in yellow, orange, and having a bright cream-coloured complexion tinged with red; fair-complexioned. For instance in the idols of northern zone we can see yellow and orange colour is predominant. Though in the middle and west parts of Tripura we can see bright cream complexion with tinged red and bright pink with tinged yellow is in predominant. As we know always goddess Kali is depicted in black colour, Shiva, Krishna and Shani Deva is depicted in blue colour, same as goddess Manasa is in the yellow, orange, and in the bright pink colour.

So, the goddess is mainly wearing yellow, orange, and red shari along with many abharana (literally meaning 'ornament', the expressions refers to the stylised decorations on the icons in human forms). The goddess worn kankana, valaya or katana (auspicious ornaments, worn in the hand, especially on the wrist, as the bangle or bracelet). There are independent idols of the Manasa and there are idols along with the Prabha-mandala in the background of the structure. Prabha-mandala also known as 'prabhavali', it is the arch of effulgence surrounding the deity, the solar orb stylistically represented in icons meant for worship. The Prabha-mandal is made of bamboo, jute, and clay, decorated with white or bright colours on top of blue backgrounds. Though it is not an integral part of the icon, it adds an artistic aura to the deity represented by the icon. It is usually elliptical in shape, sometimes but very infrequently round, and rises above the pedestal of the icon, slightly at the back of the icon, and encompasses the icon's body completely, going above the tip of the icon's crown.

During the rainy season these idols of Manasa are made and worshipped in every year. The North-eastern states of Assam and Tripura is filled up with huge and wider water belt and dense forest. People in this geographical zone thus often get confronted with various snakes, especially in the monsoon; some of them are utterly poisonous. Therefore people are furious due to fright of snake bite, which lead them into the devotion or profound admiration of the snake as a goddess. Everyone believes the human forms of the goddess and worship the idols. In Bengal monsoon indicates the Bengali months of 'Ashara' and 'Sravana'. Though there are many exceptional examples of worshiping Manasa from 'ashara-sravana' to 'vadro-ashina', total four month. In Bengal, the fifth day of the dark half of the month Ashara is celebrated as Nagapanchami, when Manasa is elaborately worshiped. The smrti text prescribed the fifth days of the month Sravana, Bhadro, Ashvina and Karttika as days sacred to the Nagas. This is because the nagas are believed to have made their appearance on earth on the fifth day of a lunar month. The first puja begun on the fifth Ashara, therefore the idol makers of Tripura and southern Assam starts tied the structure with hay and bamboo including the necessary woods for the initial steps of image making.

Among the Bengali community in the North-eastern zone of India no other gods are worshipped in that quantity which take place in the case of goddess Manasa, as the number of demand of the idols, the artisans starts their works three month before the puja. The artisans are mainly belonged to the Pal or Paul community, whose main profession is to work with clay and makes art works out of that. Other than Pal community there are Acharya, Sutrodhor, Goswami or Das etc. 
are nowadays also involved with the image making after learning the art of idol making from any master, but for the Pal community it is their traditional occupation.

If there is any special order or ritual law that the image should be made in the Permanent temple then only the artisan moves into that place, otherwise they make the goddesses in their own workshops. In this case people go and collect the idols from the artisan's workshop before the day of Puja as a pre-booking system at least a month before. The other way of collecting an idol is from the village market just before the day of puja. Everywhere in the village or in the city market like in Silchar, Agartala etc. prior to the puja day artisan's comes to sell their creation.

Since all idols are made for worship particularly, the artisan had to maintain certain rules prescribed by the ancient Indian iconographic texts. For instance, the elements of tala, tala-mana - the length and width of the goddess, their hands, and their gesture, third eye, weapons, bearer, ornaments, the uses of colour etc. are directed by the texts, which an image maker must know and obey the rules respectably. However in the living traditions we find artisans practicing the principles of image making traditionally from their forefathers.

As we can see in Tripura and Assam by the very beginning the artisans form a structure with bamboo and wood to set the armature of the idol. Side by side they take bunch of hay with fine jute thread for tying up the various figurative parts of idols and then join those parts each other systemically. The initial figures of the idol made with hay need to be tied up in the structure made by bamboo and wood. To make a tangible earthen idol this anatomical structure has a very vital role.

On the other hand sticky clay or clayey soil is brought from the ponds, cultivated land or from the river bank for making the idol. The clay preparation process includes cleaning, keeping wet for few days then cutting with spade, in addition to that fine particles of jute and hay are mixed with the clay according to the requirement. The added particles of jute and hay help to develop the strength of the idol. The first layer of the clay on the hay idol is called ekmaittya in colloquial language by the artisans of Tripura. The first layer of the clay is very thin which meant for only cover the hay. The second layer is completely thick and heavy, which called duimaittya, adds the jute mixed clay. In this case the shapes and volumes of the idols are needed to address, for instance different parts of the body (neck, hands, breast, belly, abdomen, legs etc.) need to be highlighted. In this stage careful modelling with processed clay is very much important. After that, the 'wrist-palm-finger' together are to be fixed with the hands and legs. Further one final layer is applied which called tinmaittya. This third layer is very thin which needs refined clay to maintain the polished tactile qualities of the idol's body. This thin layer of clay is applied directly with the brush. After each layer of clay the idol has to be kept few days for drying up.

Then the fixing of portraits are important for the idols. The portraits of the goddess are made according to the size of mould similar to the idol's size. We can differentiate the work of various artisans according to the characteristics of various moulds. All the portraits of goddess are different in look, but iconographically they all are Devi Manasa.

At the very beginning a primary white colour is applied on the idol, then the yellow colour, afterwards tonal variation is made by the use of orange, red, golden etc. Nowadays in the maximum workshop of Tripura they use the 'spray gun' to apply these three stages of colour. Beside this in the small workshops artisans till use brushes to decorate the idol, and they keenly draw the chiaroscuro. Afterwards they draw each and every folds of the joint with the deep colour tone. Then they focus to the portraits, followed by the eyebrows, eyes, nose, mouth, lip, along with the third eye etc. are 
drawn very carefully. Wearing the clothes of the goddess are also an important task, in the edges of the shari they fix some glistened clothes. There are many ornaments which are needed to fix in different parts of the body. Then they fix the hair of the goddess. If there is a big size image they also decorate the background or prabhamandal, by the fine lines of bush with some floral design. Besides, each and every snake and swan being decorated keenly, thus they look mostly life-full.

We can perceive the mood and essence of beauty of the goddess while deeply observing the pictorial characteristics of the portraits. For instance, in Kumarghat and Fatikroy I have found two images where the goddess looks like a dolls. It does not show the proper qualities of human emotion, by its facial expression. In contrast there are many images of the goddess found in Dharmanagar, Kailashahar, or in Petcharthal, which exactly represent the human emotion, as if they look like Bengali woman in the form of goddess. It can be assumed that all the images of the goddess Manasa found in the region of Tripura and Assam are essentially look like Bengali by the facial appearance, which may indicate the symptoms of present Bengali anthropology (Fig. 10).

It is noteworthy that each of the artisans make the different portraits of the goddess. From their individual experiences about the woman forms they depict or transform it into the images of goddess. Thus each of the woman's portraits carries their genetical information pictorially. An artist always looks deeply into the outer world and inner too, to make the image of a particular thing or the people, from their subconscious thought they transform the visuals into the conscience. In the process of image making this is a natural phenomenon. Therefore ancient Indian religious texts or shasthra tells to the artists to meditate before making an idol of any god or goddess.

However, the present tradition of Manasa artefacts in the folk art Bengal is a continuity of a larger art historical tradition of Eastern India. The archaeological remains of stone and bronze snake goddess, the medieval tradition of Manasa-mangal text, along with the living traditions of diversefolk and symbolical forms of Manasa, the image or icon also popular in the contemporary medium of arts, particularly in Bengali theatre and television.

The forms of the goddesses are of human, i.e. womanly form. They can be imagined or thought of. How much might have man considered about the godly forms of goddesses and icons. Over years, day after day. How long could have man expressed that in a piece of stone or bronze or in clay. The artist, the clan, has inherited the form of the goddess and practiced the construct of reality and imagination underneath the given heritage. These forms are meaningful to beings. These arts have 'human' as its content, whatever be the materials used. In historical times, the customs, arts, culture, religion woven in the life of man often took shapes of different gods and goddesses. Manasa is one of such phenomena and importantly it is a living tradition of Bengal or Bengali folk.

List of illustration mentioned above are attached bellow... 


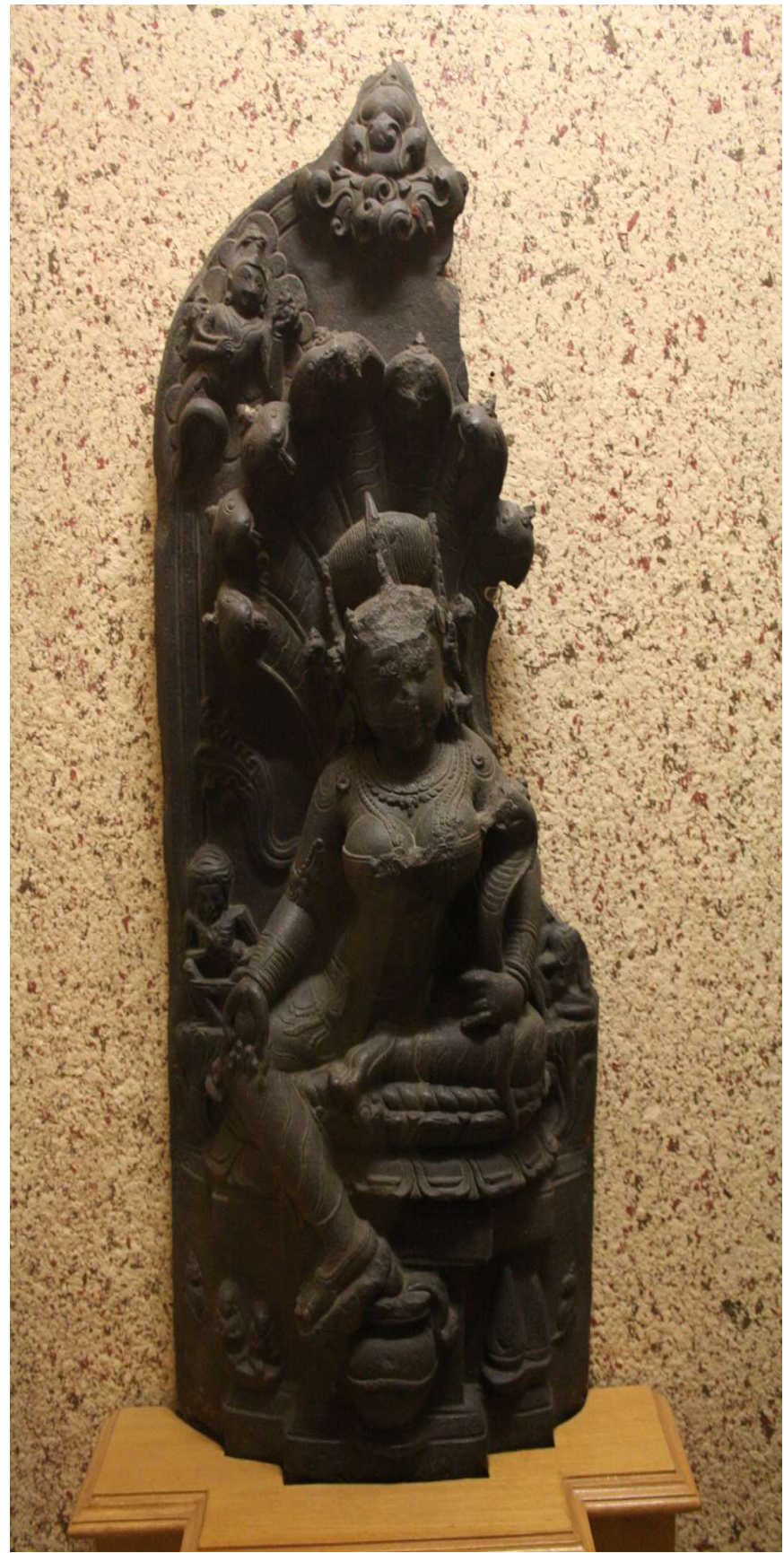

Figure 1: Seven snake hooded stylised Manasa, 11th-12th Century A.D. State Archaeological Museum, Kolkata, Accession no. 05.53. 


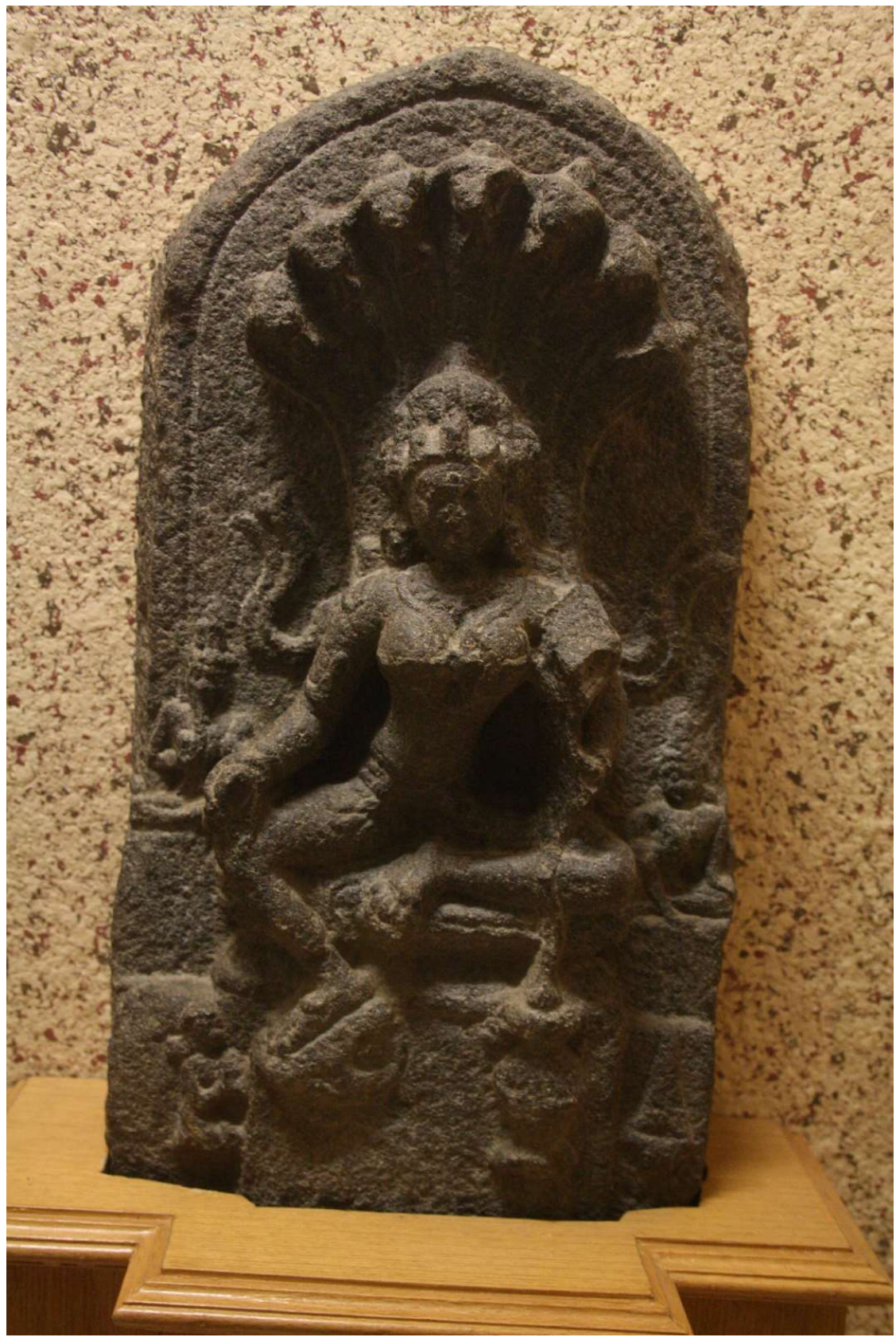

Figure 2: Seven snake hooded simplified Manasa, 12th Century A.D. State Archaeological Museum, Accession no. 05.109. 


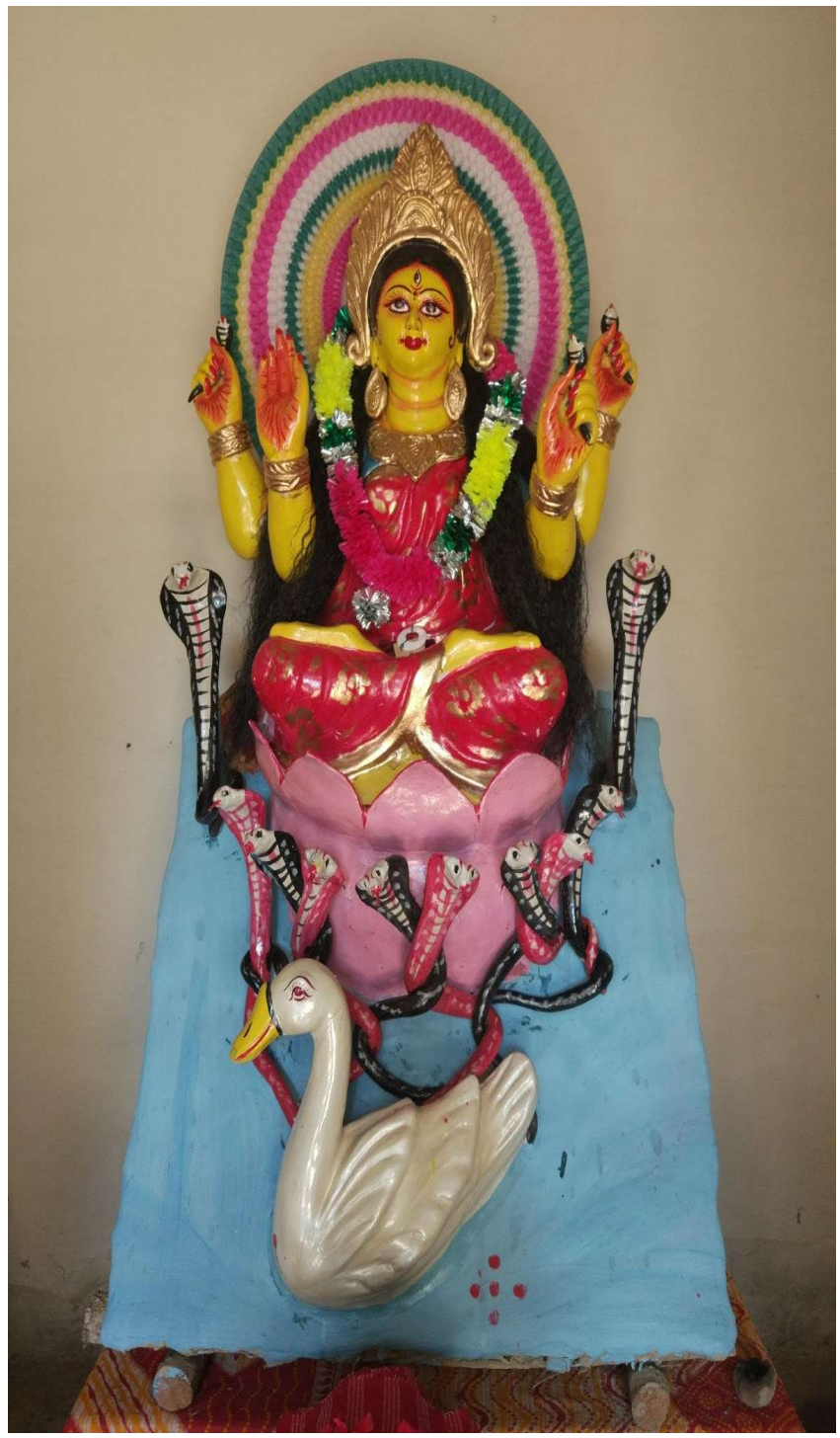

Figure 3: Manasa in Padmasana or yogini is one the significant form of the goddess from South Ganganagar, Dharmanagar, North Tripura. 


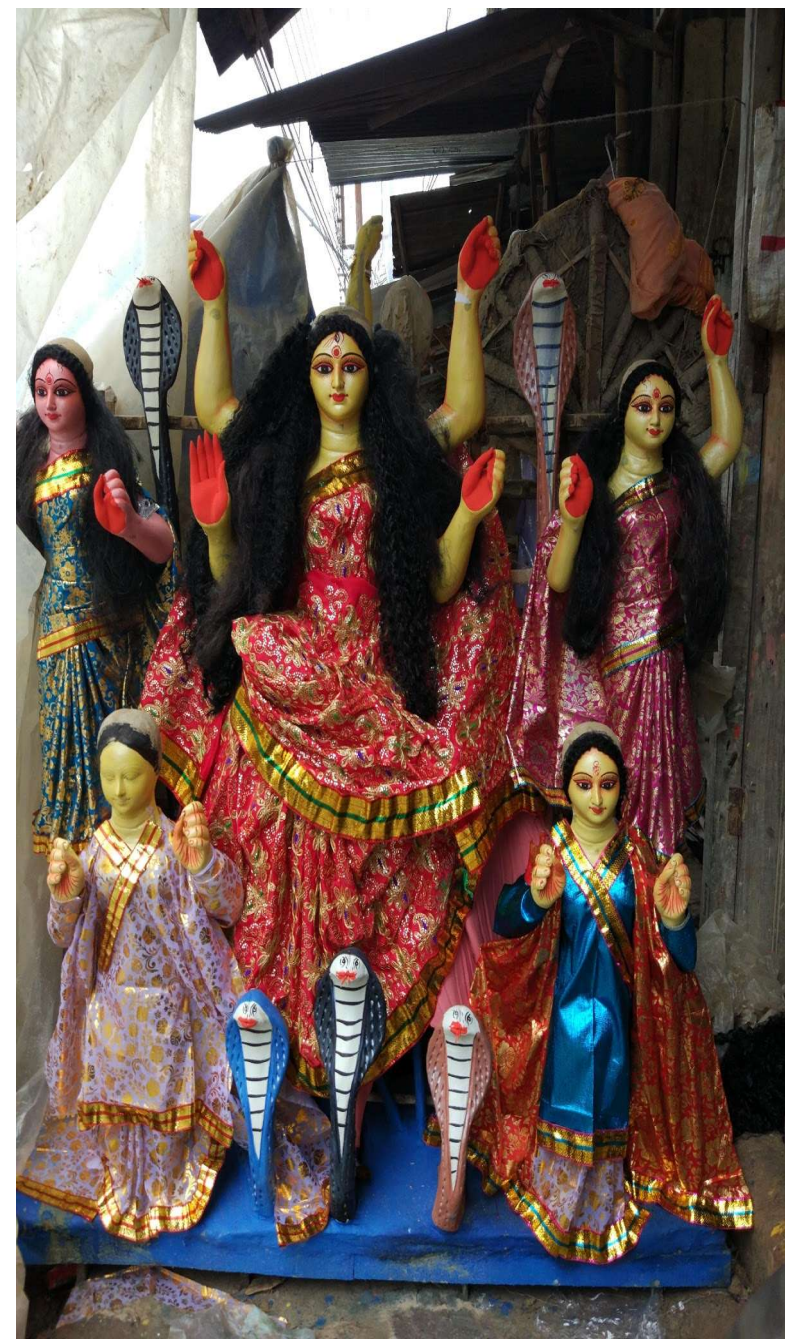

Figure 4: Manasa with Chand Sadagar, Sanaka, Behula and Lakhindar from Gandhighat, Agartala West Tripura.

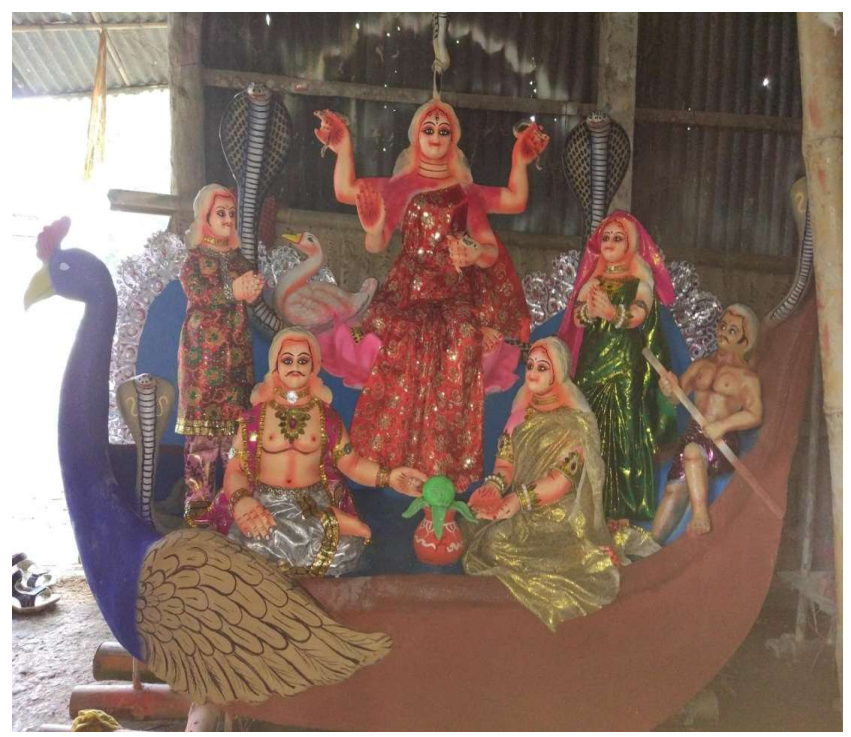

Figure 5: Manasa in boat with the attendants of the goddess found in Shib-bari, Teliamura Khowai Tripura. 


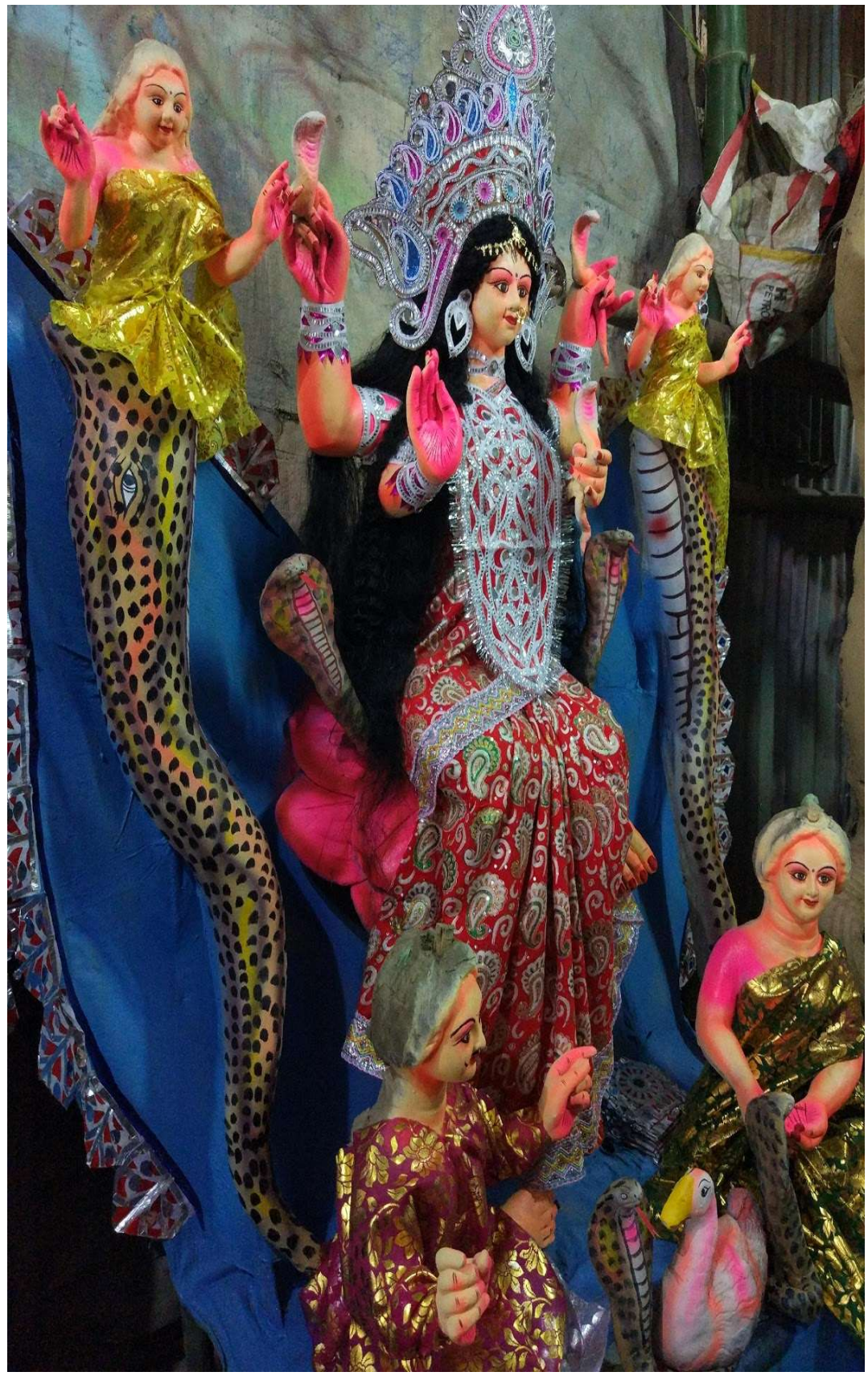

Figure 6: Manasa along with two nag-kanya (snake maiden) found in Shib-bari, Teliamura Khowai Tripura. 


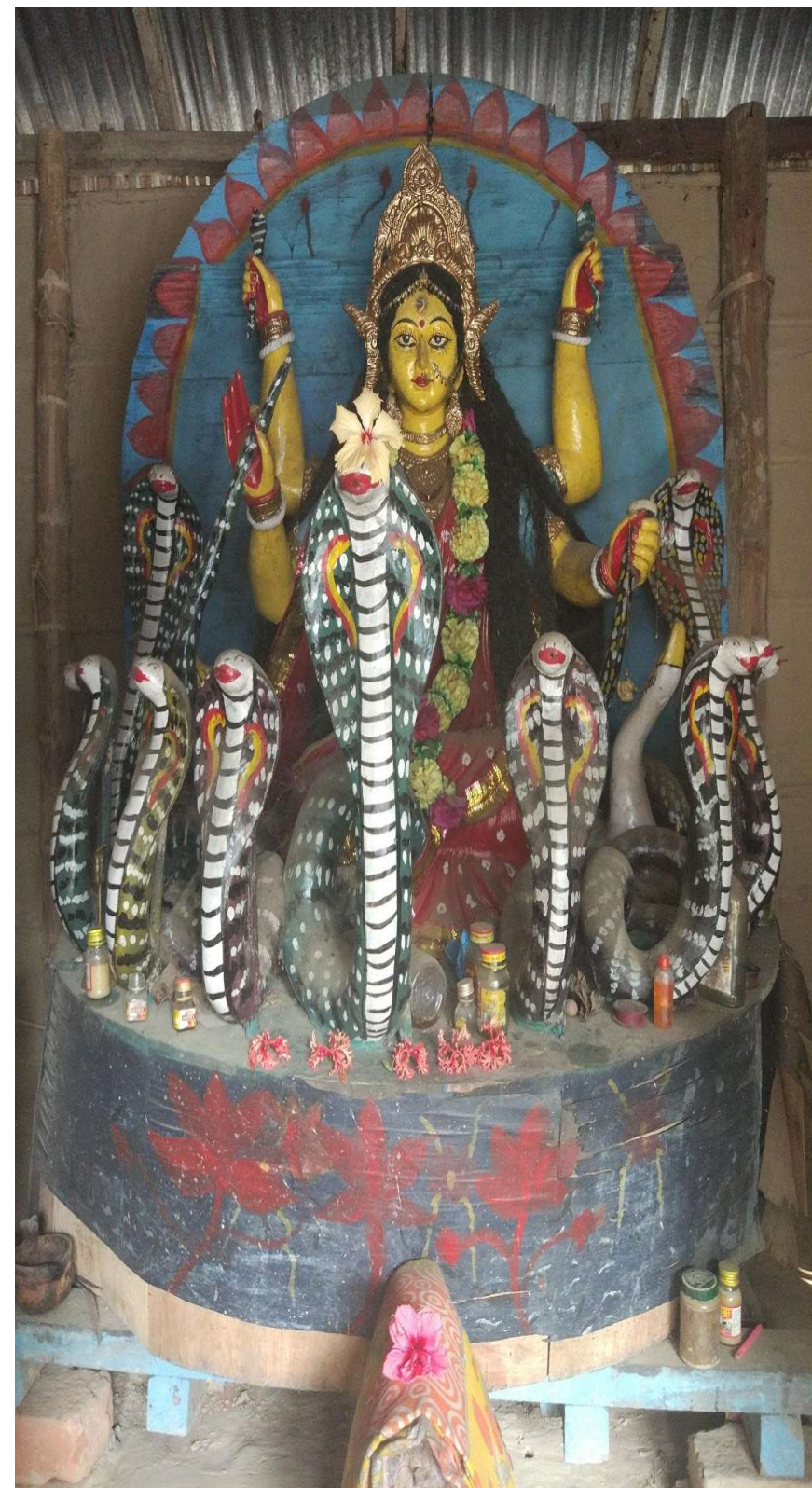

Figure 7: Nag-ratha Manasa from Telia Tee garden, Kailashahar Unakoti Tripura. 


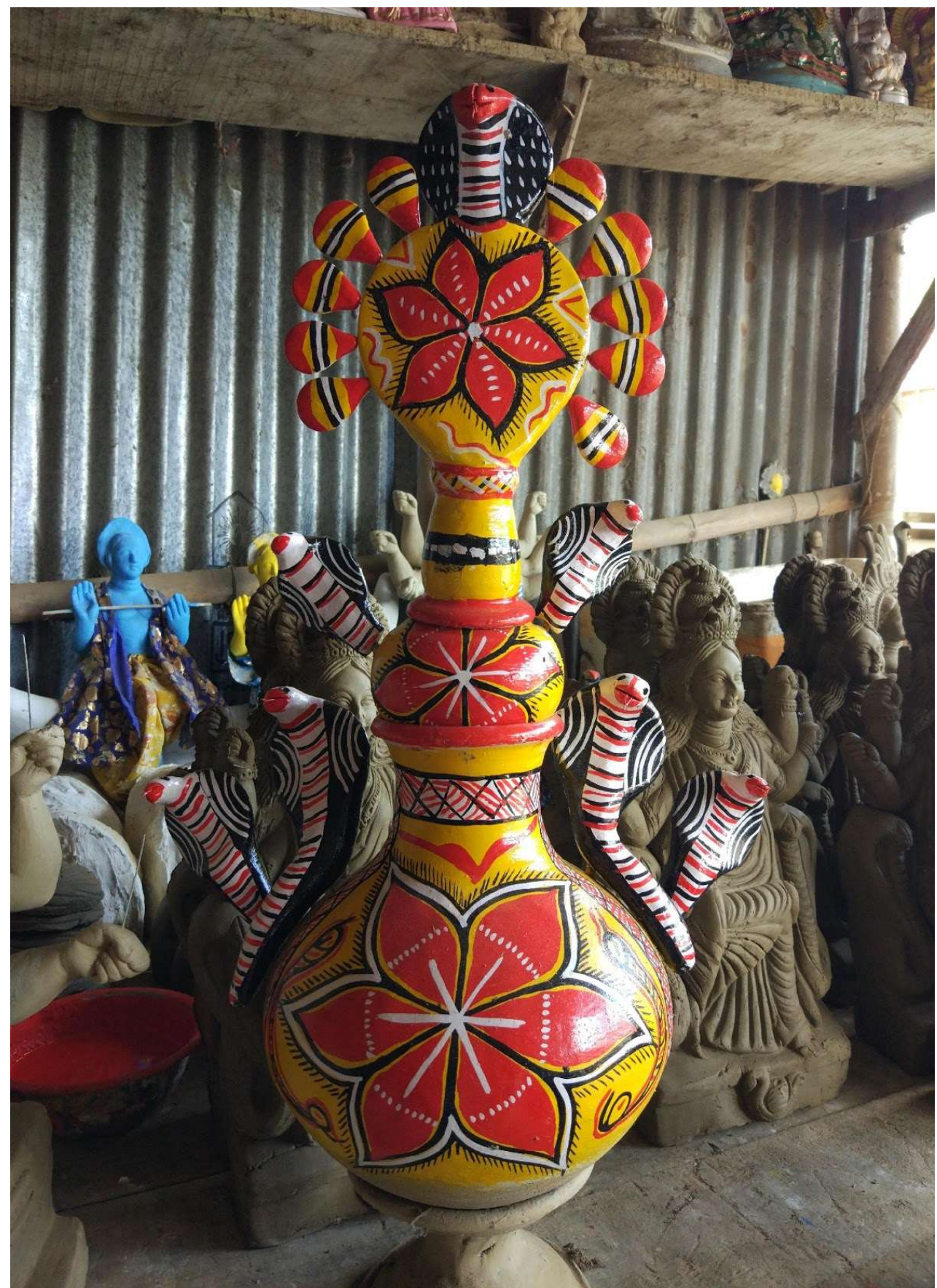

Figure 8: Manasa Ghot (pitcher) found in a workshop of artist Dipankar Pal in Shashan kalibari, Rajbari road, Dharmanagar North Tripura. 


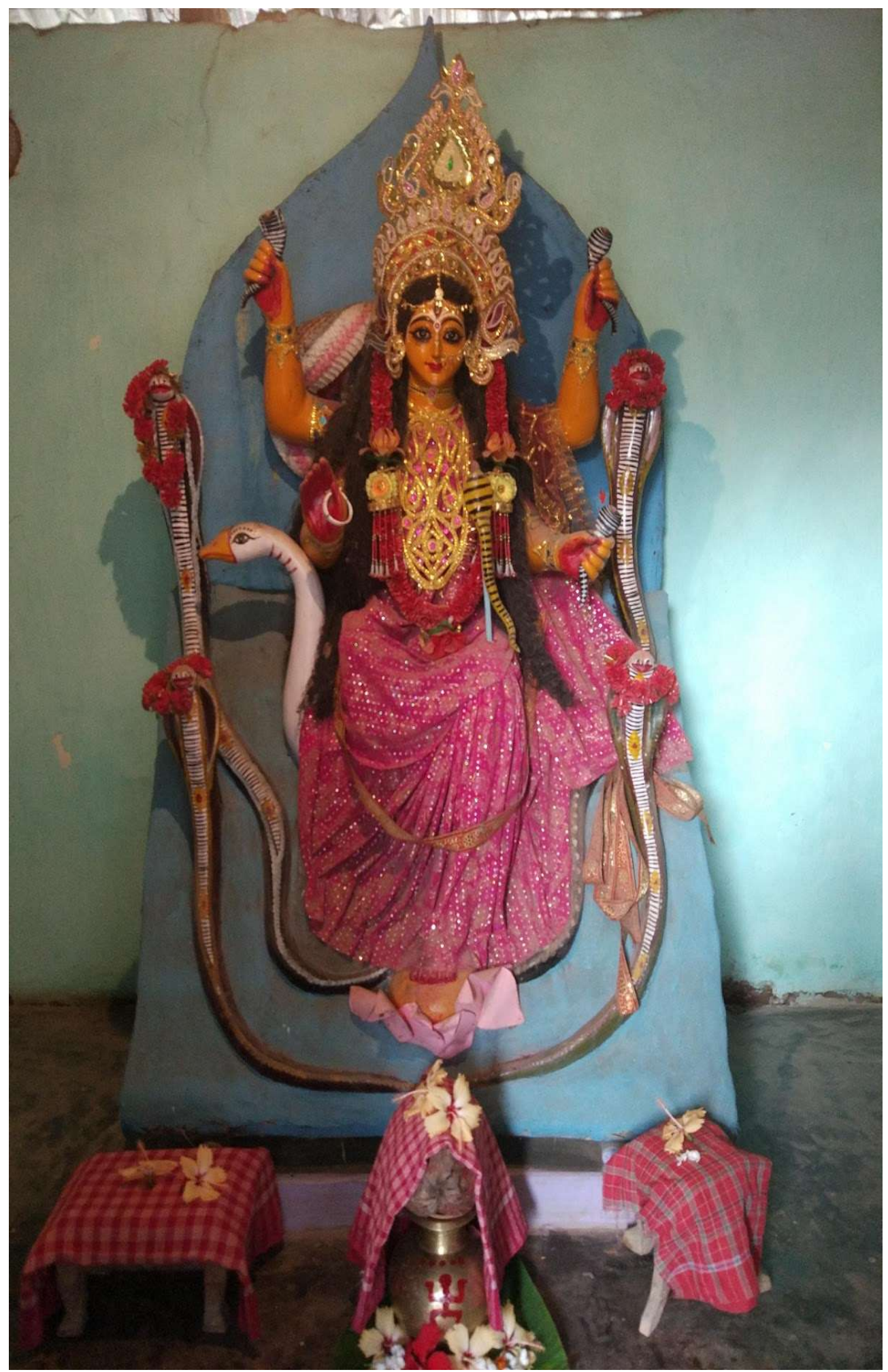

Figure 9: Most popular/luminous form of the goddess Manasa is in lalitasana gesture, from Kumarghat, Unakoti Tripura. 


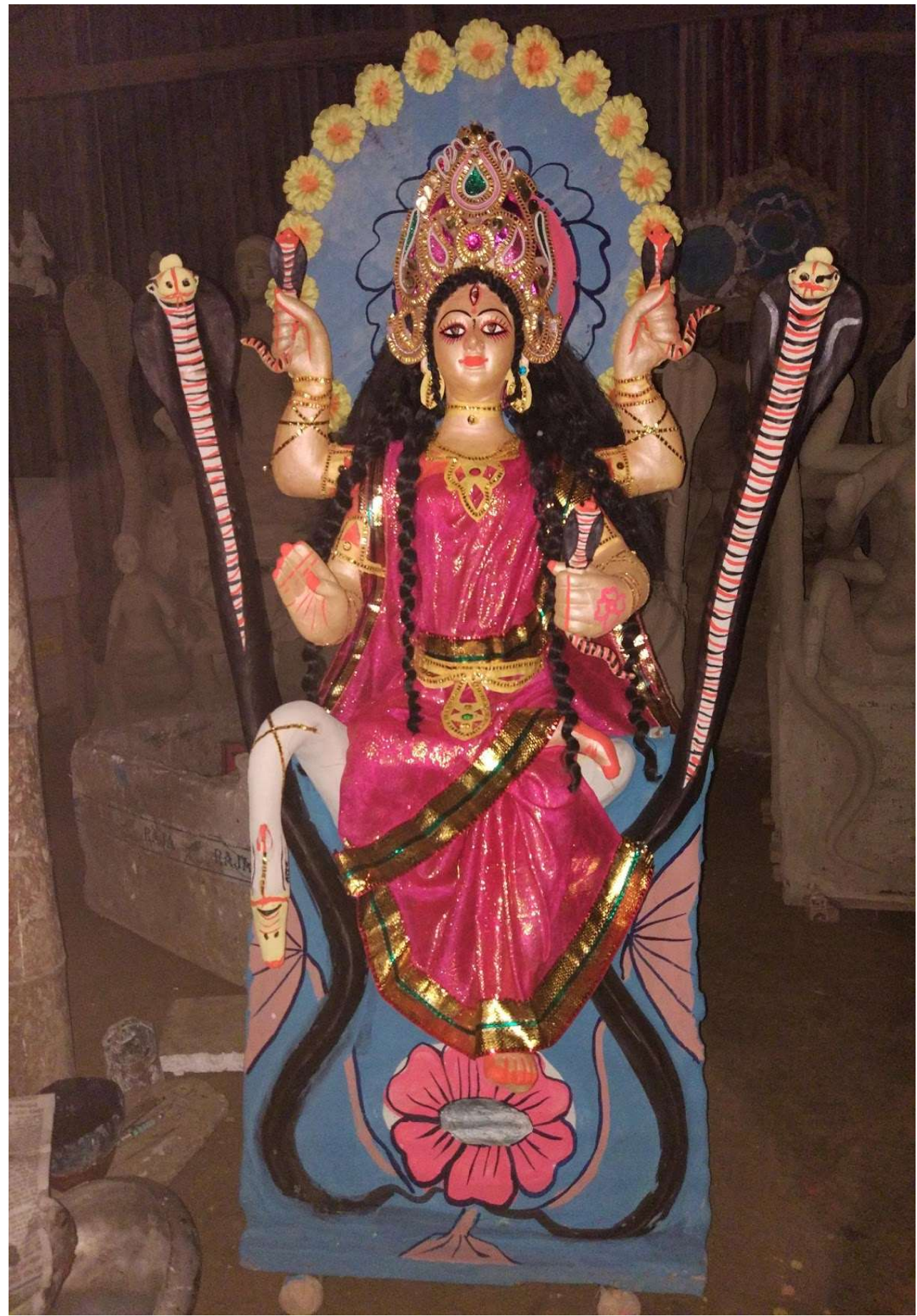

Figure 10: Manasa, from Petcharthal, Unakoti Tripura is very familiar with the Bengali anthropology.

\section{REFERENCES}

1. H. Bhuiyan. Mokamal, Studies in south Asian heritage. Essays in memory of M. Harunur Rashid. Page 99-100.

2. H. Bhuiyan, Mokammal. Iconography of Goddess Manasa: Origin, Development and Concept.

3. John Bathurst Deane, The Worship of the Serpent, London, 1830, page 12.

4. The term Kavya, "poetry," does not have the technical significance that it does in Sanskrit poetics, nor does it refer here to the type of classical poetry often indicated by the term. 
5. T. W. Clark, "Evolution of Hinduism in Medieval Bengali Literature," Bulletin of the School of Oriental and African Studies, XVII, 514.

6. Sen, D. C. History of Bengali Language and Literature, Page 252-276.

7. T. Richard Blurton, Bengali Myths, The British Museum Press, p. 13-14.

8. Sen, D. C. History of Bengali Language and Literature, pp. 252-276.

9. Sen, D. C. Bangla Vasha O Sahitya, p. 106-117; Banga Sahitya Parichaya, Part I, Intro. p. 19-20 and p.172-174

10. Bhattasali, Nalinikanta. Iconography of Buddhist and Brahmanical Sculptures in the Dacca Museum, p. 218-226

11. H. Bhuiyan, Mokammal. Iconography of Goddess Manasa: Origin, Development and Concept.

12. Bhattacharya, Ashotosh. Bangla Mangal Kavyer Itihas, p. 160-220 and Banglar Lokosruti, 1985, p. 107-157

13. Swami, Sankarananda. Manasa Charita, First ed. 1957, p. 1-30

14. L. S. S. O`Malley, B.D.G. Bankura, pp. 51; Birbhum, pp. 33; Hooghly, pp. 104; 24 Parganas, pp. 71-72; L.L.S. O`Malley and M. M. Chakravarty, B.D.G. : Howrah, pp. 43-44; J. C. K. Peterson, B.D.G. : Burdwan, pp. 55-56; E. A. Sachse, B.D.G. : Mymensingh, pp. 36' H. Coupland, B.D.G. : Manbhum, pp. 94; J. C. Jack, B.D.G. : Bakarganj, pp. 36; J. N. Gupta, Eastern Bengal and Assam District Gazetteers: Bogra, pp. 38; J. F. Gruning: E.B.A.D.G : Jalpaiguris, pp. 32; J. A. Vas, E.B.A.D.G : Rangpur, pp. 45; J. E. Webster, E.B.A.D.G : Noakhali, pp. 35.

15. W.J. Wilkins, Modern Hinduism, pp. 225-226; H.H. Risley, The Tribes and Castes of Bengal, Vol. I, pp. 41, 80, 84, 187, 227, 270, 290, 454, 457, 498, 499, 509, 517, 523; Vol. II, pp. 23, 42, 49, 264; J. Ph. Vogel, Indian Serpent Lore, pp. 278; E.R.E. Vol. XI, pp. 413; History of Bengal, Vol. I, pp. 460-61; P. L. Paul, The Early history of Bengal, Vol. II, pp. 106; B. A. Gupta, Hindu Holidays and Ceremonies, pp. 140- 44; B. K. Barua, A Cultural History of Assam, Vol. I, pp. 141, 193-95; N. R. Ray, Banglar Itihas, (Adi parva) pp. 588-89; T. C. Das Gupta, Prachin Bangla Shatter Itihas, pp. 91-100; S. Sen, Bangla Sahityer Itihas, Vol. I, pp. 155-203; P. C. Chaudhury, The History of Civilization of the People of Assam, pp. 372, 419, 457, 498; Swamy Sankarananda, Manasa Charita, pp. 1-152; E. O. James, The Cult of the Mother Goddess, pp. 119; M. Gosh, Bangla Sahitya, pp. 68-69.

16. Swami, Sankarananda. Manasa Charita, First ed. 1957, Page 1-152.

17. Sen, Anjan \& Sk. Makbul Islam. Sarpa Sanskriti O Manasa, A collection of essays on Serpent-cult and Manasa. Bangiya Sahitya Samsad, Kolkata, 2012, page 49-55.

18. Author Name: NILKANTA DAS. AuthorEmail: nillkanta.das@gmail.com

19. Author Mobile: 8116066943. WhatsApp number: 6009227856. Country: India

20. LinkedIn Profile: https://www.linkedin.com/in/nilkanta-das-al66a166/

21. FB Profile: https://www.facebook.com/nillkanta.das.9

22. TAHMINA, SHAHZADI, and M. U. H. A. M. M. A. D. AL MAHMUD. "INDIAN SUB-CONTINENTAL NATIONALIST AND JAPANS ROLE FOR THE EMERGENCE OF BENGALI NATIONALISM." International Journal of History and Research (IJHR) 8.1, Jun 2018, 1-10

23. VASANI, MEERA. "BREATHING THE UNIQUENESS OF KUNKANA CULTURE BY WORD-OF-THE MOUTH TRADITION." International Journal of English and Literature (IJEL) 8.5, Oct 2018, 19-24

24. Khondker, Shirajom Monira, and Mehnaz Tabassum. "Kashinath Bhaban: A Unique Building of Panam Nagar Bears Testimony to Colonial Architecture in Bengal." IASET-International Journal of Civil Engineering (IJCE) 2.3 (2013): 97-108. 
25. SALUNKE, DS. "THEMATIZING POLITICAL TRANSITION WITH REFERENCE TO PAULSCOTT'S SIX DAYS IN MARA PORE." International Journal of Linguistics and Literature (IJLL)5. 5, Aug - Sep 2016; 19-24 